\title{
Effect of NAFTA, EUMFTA and China addition to WTO on the cucumber world market
}

\section{(Efectos de NAFTA, EUMFTA y la incorporación de China en el mercado mundial del pepino) ${ }^{*}$}

\author{
Ramón Guajardo-Quiroga \\ Universidad Autónoma de Nuevo León, Centro de Estudios Asiáticos, San Nicolás de los \\ Garza, N.L., México, rguajardoq@yahoo.com
}

Key words: Cucumber world market, international trade, economic integration, quadratic programming, spatial equilibrium models.

\begin{abstract}
This study empirically analyzed the potential effects of the complete operation of North American Free Trade Agreement (NAFTA), European Union and Mexico Free Trade Agreement (EUMFTA), and the integration of China to the World Trade Organization (WTO), on the cucumber world market. Special emphasis on the impact on Mexico was presented, from a worldwide perspective. A spatial equilibrium model with endogenous prices was constructed for this purpose. Among the findings are: (1) Mexican producers benefited from the complete implementation of NAFTA and EUMFTA. (2) The incorporation of China as a member of the WTO showed a negligible effect on the commercial flows and prices in the cucumber world market. (3) Mexican cucumber production is highly competitive, in the world market, because it has the lowest supply costs.
\end{abstract}

Palabras Clave: Mercado mundial del pepino, integración económica, comercio internacional, programación cuadrática, modelos de equilibro espacial.

Resumen. Este estudio analiza empíricamente los efectos potenciales de la operación completa del Tratado de Libre Comercio de América del Norte (TLCAN), Tratado de Libre Comercio de la Unión Europea y México (UMFTA), y la integración de China a la Organización Mundial de Comercio (OMC) en relación al mercado mundial del pepino. Se presentan, con énfasis especial, los impactos sobre México desde una perspectiva mundial.

\footnotetext{
* This study was sponsored by the Universidad Autónoma de Nuevo León (PAICYT, grant CT111-09).
} 
Para lograr los propósitos del estudio se construye un modelo de equilibrio espacial con precios endógenos. Entre los resultados se mencionan los siguientes: (1) Los productores mexicanos se benefician con la operación completa de TLCAN y EUMFTA. (2) La incorporación de China como miembro de la OMC no muestra efectos significativos en los flujos comerciales y precios en el mercado mundial del pepino. (3) La producción mexicana de pepino es altamente competitiva, en el mercado mundial de pepino, como resultado de sus bajos costos de producción.

\section{Introduction}

During the last two decades, several countries have increasingly adopted market-oriented policies and have moved towards economic integration and greater participation in world trade. In particular, Mexico has signed several commercial agreements among them are The North American Free Trade Agreement (NAFTA) and European Union and Mexico Free Trade Agreement (EUMFTA).

NAFTA resulted in a significant increase in trade between Mexico and the United States (US). Specifically, NAFTA boosted Mexico's exports of horticultural commodities to the US. In 2009, Mexican horticultural exports have surpassed 3.5 billion dollars (ERS/USDA). Among the most important export commodities are tomatoes, peppers, eggplants, asparagus, pumpkins and cucumbers. For this last commodity, since 1999, Mexico has been among the leaders in exports (FAOSTAT).

The major agricultural issues addressed in NAFTA are tariffs, safeguards for producers, rules of origin, no tariff barriers, and sanitary and phytosanitary regulations; it also included provisions to deal with dispute settlement procedures, investments, intellectual property protection, and transportation. Most tariffs were eliminated within 10 years, and duties on a few highly sensitive products were phased out by the year 2008 (SECOFI, 1994).

The second major free trade agreement in which Mexico participates is with the European Union (EU) that went into effect in July 2000. The European Union and México Free Trade agreement (EUMFTA) also incorporates staggered tariff elimination, with complete implementation by 2008 (SECOFI, 2000). However, until now the impact of EUMFTA on trade has been minor, since only NAFTA represent around $80 \%$ of Mexican trade (ERS/USDA). 
China, the world's fourth largest economy, joined the World Trade Organization (WTO) in 2001. China is a major player in international markets and a major source of growth in world demand for agricultural products since the mid-1990. In 2008, China's agricultural exports totaled an estimated US $\$ 28$ billion and its agricultural imports totaled US\$57 billion (ERS/USDA). Most of its exports go to neighboring countries in Asia. China has and will continue to be subject to intense international scrutiny as its role in the global economy expands.

The main purpose of this paper is to analyze the impact of NAFTA, EUMFTA and the integration of China to the WTO on the cucumber world market. A spatial equilibrium model with endogenous prices was constructed for this purpose. Several scenarios were enabled to model the application of the commercial policies from NAFTA and EUMFTA treaties and the resulting economic impact on the market. In addition, a special emphasis was placed on how Mexico has been impacted.

The basic approach was to estimate the effects of changes in commercial policy on commodity supply, demand, and prices for the main countries and regions that produce, consume, export, and import this commodity. The solutions were calculated using quadratic mathematical programming and the solution of the model yielded supply and demand equilibrium quantities and prices for each region, as well as, production and consumption quantities, export and import quantities, from modeled changes in commercial policies in world market perspective.

The rest of the study is outlined as follows: Section II presents an overview of the cucumber world market, Section III, reviews the methodology and the model used, Section IV presents the application of the model and its results, and finally, concluding remarks are presented in Section V.

\section{Cucumber world market}

The cucumber is one of the most important vegetables in the world market. It is consumed both as fresh and processed. The export value has grown nearly $10 \%$ annually from 1994 to 2007. During 2007, 40.9 million Metric tons (Mt) of cucumbers and pickles were exported, for an approximate value of 14 billion dollars at producer prices. The main producer region is Asia 
with almost $82 \%$ of the world production, followed by the NAFTA members with $4.7 \%$, the EU with $4.4 \%$ and the rest of the world with $8.9 \%$ (FAOSTAT).

There are six main cucumber producers in the world with China being the leader, producing $63 \%$ of the world's production with 28.2 Million Mt in 2008 (by far, it is the single largest cucumber producer and consumer in the world, however until now this production is mainly used for domestic consumption). Following in second is Turkey producing 1.68 million Mt. The remaining four main producers are Iran with 1.46 million Mt, Russia with 1.13 million Mt, the US with 0.92 million Mt, and Japan contributing 0.63 million Mt; Mexico, although a leading country because of its exports, ranks twelfth with only $1.15 \%$ of the world's production with $420,000 \mathrm{Mt}$.

Focusing attention to international commerce, in the last decade, it is notable that the production sharing is very different from that of the interregional trade flows because four out of five of the world main producers, being China, Turkey, Iran, and Russia, dedicate the whole of their production to domestic consumption alone. Fifty percent of the international trade takes place in the EU. In addition, close to ninety percent of the export value takes place in the countries that belong to NAFTA and the EU.

During 2007, a world total value of cucumber exports amounted to 1.9 billion dollars, where $60 \%$ of this value corresponded to the $\mathrm{EU}$ and $30 \%$ to NAFTA. The three main exporting countries were Spain, the Netherlands, and Mexico; together their export value amounted to $78 \%$ of the world total export value. The main importing countries in 2007 were Germany, the US, and the United Kingdom amounting to $64 \%$ of the world import value (Table 1). It is important to note that the main importing countries are commercial partners with Mexico.

Since the signing of NAFTA, Mexico's cucumber production increased from 262,017 Mt in 1994 to 428,374 Mt in 2007, which is an increment of 63\% for the analyzed period. In addition, Mexican export values increased from US $\$ 139$ million to US $\$ 447$ million. The main destiny of Mexican cucumber exports is US that account for $90 \%$ and the rest went to Canada. The enhanced trade is due to several reasons. Among them are that all tariffs, quotas, and licenses that were barriers to the cucumber trade between the US and Mexico were eliminated because of NAFTA and the relative low transportation cost between these two countries, resulting in a boost in production and exports of agricultural commodities in Mexico. 
Table 1. Main export and import countries of cucumbers

\begin{tabular}{|l|c|r|}
\hline \multicolumn{3}{|c|}{ Exports (thousand US dollars) } \\
\hline & $\mathbf{1 9 9 4}$ & $\mathbf{2 0 0 7}$ \\
\hline Spain & 127,728 & 479,981 \\
\hline Netherlands & 378,090 & 432,518 \\
\hline Mexico & 139,360 & 447,304 \\
\hline US & 21,925 & 55,776 \\
\hline Rest of the World & 147,863 & 462,707 \\
\hline \multicolumn{3}{|c|}{ Imports (thousand US dollars) } \\
\hline \multicolumn{3}{|c|}{1994} \\
\hline Germany & 348,175 & $\mathbf{2 0 0 7}$ \\
\hline US & 125,632 & 502,219 \\
\hline United Kingdom & 50,344 & 471,380 \\
\hline Netherlands & 69,747 & 170,674 \\
\hline Rest of the World & 822,893 & 92,586 \\
\hline Source: Based on FAOSTAT. & 668,505 \\
\hline
\end{tabular}

\section{Methodology and the model}

The spatial equilibrium models with endogenous prices have been frequently used to study interregional competence for a specific product. Mathematically these are quadratic programming problems. Enke (1951) and Samuelson (1952) are the pioneers of these models working with the equilibrium of supply and demand functions. Later, Takayama and Judge (1971) improved them to deal with situations in which production and consumption occurs in spatially separated regions. Trade then occurs, if the difference in regional prices is larger than transportation cost. Recently, further developments were incorporated mainly on solution algorithms.

These models are an extension of the transportation model, but with equilibrium prices and quantities determined endogenously. They are useful to simulate the impact caused on the market by the application of commercial policies. These models are frequently used in agricultural economics to analyze interregional market flows (Kawaguchi, et al., 1998; Kennedy and Atici, 1998; Kennedy and Hughes, 1998; Guajardo and Elizondo, 2003).

The spatial equilibrium model can be expanded to handle with multiple markets, transport costs, tariffs, quotas, and subsidies, among others. It also 
permits the incorporation of any degree of market structure from perfect competition to monopoly. Kawaguchi, et al. (1998) used several market structures to study the milk market in Japan and in the US.

Another application for these models is to study interregional competition of agricultural products. For instance, Guajardo and Elizondo (2003) studied the North American Tomato Market from a spatial equilibrium perspective and Guajardo and Villezca (2004) studied the avocado market in NAFTA.

The spatial equilibrium model uses inverse linear supply and demand functions with endogenous price. Expanding the model to ith region, the inverse demand function in the $i^{\text {th }}$ region is:

$$
\begin{aligned}
& P_{d i}=P_{d i}\left(Q_{d i}\right)=\alpha_{d i}-\beta_{d i} Q_{d i}, \\
& \text { Where: } P_{d i}=\text { Demand price in region } i . \\
& Q_{d i}=\text { Quantity demanded in region } i .
\end{aligned}
$$

The inverse supply function for the $i^{\text {th }}$ region is:

$$
P_{s i}=P_{s i}\left(Q_{s i}\right)=\alpha_{s i}+\beta_{s i} Q_{s i},
$$

Where: $P_{s i}=$ Supply price in region $i$.

$Q_{s i}=$ Quantity supplied in region $i$.

The quasi-welfare function $\left(W_{i}\right)$ of each region results from subtracting integral underneath the inverse supply function from the integral underneath the inverse demand function the regional supply:

$$
W_{i}\left(Q_{s i}^{*}, Q_{d i}{ }^{*}\right)=\int_{0}^{Q d i^{*}} \mathrm{P}_{\mathrm{di}}\left(\mathrm{Q}_{\mathrm{di}}\right) d Q_{d i}-\int_{0}^{\mathrm{Qsi}^{*}} \mathrm{P}_{\mathrm{si}}\left(\mathrm{Q}_{\mathrm{si}}\right) d Q_{s i},
$$

The total welfare function across all regions is the sum of the welfare functions in each region. The transaction costs $\left(T_{i j}\right)$ are subtracted from the total welfare function to obtain the net welfare function NW.

$$
N W=\sum_{i} W_{i}\left(Q_{s i}^{*}, Q_{d i}^{*}\right)-\sum_{i} \sum_{j} C_{i j} T_{i j},
$$

Where: $C_{i j}=$ the unit cost of transportation plus specific tariffs from producers of region $i$ to consumers in region $j$; $T_{i j}=$ the quantity transported from region $i$ to region $j$. 
To form an optimization model with the expression NW as the objective function two sets of restrictions regarding supply and demand balances were incorporated. The first set of restrictions establish that each regional demand is less than or equal to domestic supply plus imports.

$$
Q_{d i} \leq \sum_{j} T_{i j} \text { for all } i,
$$

The second set of restrictions establishes that the each regional supply is greater than or equal to domestic consumption plus exports.

$$
Q_{s i} \geq \sum_{j} T_{i j} \text { for all } i,
$$

The model that includes the objective function (4) and sets of the equations (5) and (6) as restrictions, plus the nonnegative conditions of the supply, demand, and the transport quantities being greater or equal to zero is as follows:

$$
\begin{gathered}
\operatorname{Max} \sum_{i}\left(\int_{0}^{Q d *^{*}} \mathrm{P}_{\mathrm{di}}\left(\mathrm{Q}_{\mathrm{di}}\right) d Q_{d i}-\int_{0}^{\text {Qsi* }} \mathrm{P}_{\mathrm{si}}\left(\mathrm{Q}_{\mathrm{si}}\right) d Q_{s i}\right)-\sum_{i} \sum_{j} C_{i j} T_{i j}, \\
\text { Subject to: } \\
Q_{d i}-\sum_{j} T_{i j} \leq 0 \text { for all } i \\
-Q_{s i}+\sum_{j} T_{i j} \leq 0 \text { for all } i, \\
Q_{d i}, Q_{s i}, T_{i j} \geq 0 \text { for all } i \text { and } j
\end{gathered}
$$

This is a quadratic programming problem. The general form maximizes the sum of the areas underneath the inverse demand curves minus sum of the integral underneath the inverse supply curve minus transaction costs, subject to the supply-demand balance. The model formulation assumes that the supply and demand equations are integrable and commodity demand and factor supply functions are truly exogenous to the model (i.e. there are no income effects). Both consumers and producers are price takers and consequently neither can individually influence output or factor prices. 
If the inverse demand equations have a negative slope and the inverse supply functions have a positive slope, equilibrium is then feasible. Introducing a Lagrange function.

The Lagrange function associated with the optimization problem is:

$$
\begin{gathered}
L=\sum_{i=1}^{n}\left[\int_{0}^{Q d d^{*}} \mathrm{P}_{\mathrm{di}}\left(Q_{d i}\right) d Q_{d i}-\int_{0}^{\mathrm{Qsi}} \mathrm{P}_{\mathrm{si}}\left(Q_{s i}\right) d Q_{s i}\right]-\sum_{i=1}^{n} \sum_{j=1}^{n} C_{i j} T_{i j}+\sum_{i=1}^{n} \lambda_{d i}\left[Q_{d i}-\sum_{j=1}^{n} T_{i j}\right]+\sum_{i=1}^{n} \psi_{s i}\left[\sum_{j=1}^{n} T_{i j}-Q_{s i}\right], \\
Q_{d i}, Q_{s i}, T_{i j}, \lambda_{d i}, \psi_{s i} \geq 0
\end{gathered}
$$

The relevant Kuhn-Tucker optimality conditions for the maximization problem can be expressed as follows:

$$
\begin{array}{lll}
\frac{\partial L}{\partial Q_{d i}}=P_{d i}-\lambda_{d i} \leq 0 ; & \text { and } \quad\left(\frac{\partial L}{\partial Q_{d i}}\right) Q_{d i}=0 ; & \text { if } \quad Q_{d i} \geq 0 ; \\
\frac{\partial L}{\partial Q_{s i}}=-P_{s i}+\varphi_{s i} \leq 0 & \text { and }\left(\frac{\partial L}{\partial Q_{s i}}\right) Q_{s i}=0 ; & \text { if } \quad Q_{s i} \geq 0 ; \\
\frac{\partial L}{\partial T_{i j}}=-C_{i j}+\lambda_{d i}-\varphi_{s i} \leq 0 & \text { and }\left(\frac{\partial L}{\partial T_{i j}}\right) T_{i j}=0 ; & \text { if } \quad T_{i j} \geq 0 ; \\
\partial L \partial \lambda_{d i}=-Q_{d i}+\sum T_{i j} \geq 0 & \text { and }\left(\frac{\partial L}{\partial \lambda_{d i}}\right) \lambda_{d i}=0 ; & \text { if } \quad \lambda_{d i} \geq 0 ; \\
\partial L \partial \psi_{s i}=Q_{s i}-\sum T_{i j} \geq 0 & \text { and } \quad\left(\frac{\partial L}{\partial \psi_{s i}}\right) \psi_{s i}=0 ; & \text { if } \quad \psi_{s i} \geq 0 ;
\end{array}
$$

The Lagrange multipliers (dual variables) are $\lambda$ and $\psi$. $\lambda_{\text {di }}$ represents the demand shadow price or the price that the consumers are willing to pay for the good in the ith market. $\psi_{s i}$ represent the supply shadow price or the price at which the producers from the $i^{\text {th }}$ region can sell to the market. 
The Lagrange multipliers (dual variables) are $\lambda$ and $\psi$. $\lambda_{\text {di }}$ represents the demand shadow price or the price that the consumers are willing to pay for the good in the $i^{\text {th }}$ market. $\psi_{s i}$ represent the supply shadow price or the price at which the producers from the ${ }^{i \text { th }}$ region can sell to the market.

The first set of equations (11a) implies that the demand price equals its shadow price on region $i$, if the quantity demanded is positive and greater than zero. The second set of equations (11b) implies that the supply price is equal to the shadow price if the quantity supplied is positive. The third set of equations (11c) implies that the demand shadow price is equal to the transaction cost, and the supply shadow price, if the quantity transported is positive. The fourth set of equations (11d) implies that supply is equal to demand (all goods produced are being consumed) if the marginal valuation from the demand side (the demand shadow price) is positive or zero. The last set of equations (11e) implies that supply is equal to demand if the marginal valuation from the supply side (marginal opportunity cost of resources or supply shadow price) is positive or zero. From the presentation, the model can allow for different market structures.

\section{Application of the model}

The model was constructed from a world spatial perspective, and in particular, to provide an in-depth study of the impacts on the cucumber market derived from the integration of commercial blocks such as NAFTA, UEMFTA, the integration of China to the WTO and to estimate the changes derived from changes in commercial policies. In this study, six regions were taken into consideration: Mexico, US, Canada, EU (includes the following countries: Austria, Belgium, Denmark, Finland, France, Luxemburg, Germany, Greece, Ireland, Italy, Netherlands, Portugal, Spain, Sweden and United Kingdom), China, and the Rest of the World.

The supply and demand functions were estimated using linear equations. For their estimation, data from FAOSTAT was used: producer prices, import prices, export prices, population, consumption, production, and cultivated area. The estimated supply and demand equations for the regions are presented in Table 2. 
Transportation costs estimates were collected from worldwide operating multimodal companies. Rulewave de Mexico S. A. de C. V. and Grupo Proa S. A. de C. V. were two of the consulted companies as well as the Internet site "Today's Market Price".

Table 2. Estimated Supply and Demand Functions for the 6 Regions

\begin{tabular}{|c|c|c|}
\hline Region & Supply & Demand \\
\hline Mexico & $\begin{array}{l}P_{0}=114.6+0.0009 Q_{0} \\
(0.0666)^{* *+} \quad(0.1203) \\
R^{2}=0.8213\end{array}$ & $\begin{array}{l}P_{d}=\underset{(0.0453)}{735.93}-0.001039 Q_{d} \\
(0.0849) \\
R^{2}=0.8654\end{array}$ \\
\hline US & $\begin{array}{l}P_{0}=\underset{(0.0118)}{-535.09+0.001035 Q_{0}} \\
R^{2}=0.9745\end{array}$ & $\begin{aligned} P_{d}= & 4,577-0.002808 Q_{d} \\
& (0.0557) \\
R^{2}= & 0.8215\end{aligned}$ \\
\hline Canada & $\begin{array}{l}\mathrm{P}_{0}=\underset{(0.0232)}{540.9+000731 \mathrm{Q}_{0}} \\
\mathrm{R}^{2}=0.9214\end{array}$ & $\begin{array}{l}P_{d}=\underset{(0.0749)}{835.43}-0.000730 Q_{d} \\
(0.0584) \\
R^{2}=0.9302\end{array}$ \\
\hline EU & $\begin{array}{l}P_{0}=\underset{(0.0302)}{-402.5}+0.000647 Q_{0} \\
(0.0283) \\
R^{2}=0.7959\end{array}$ & $\begin{array}{l}P_{d}=\underset{(0.2512)}{1,325.4}-0.000427 Q_{d} \\
(0.0308) \\
R^{2}=0.7913\end{array}$ \\
\hline China & $\begin{array}{l}\mathrm{P}_{0}=\underset{(0.0411)}{-503.5+0.000057 Q_{0}} \\
\mathrm{R}^{2}=0.8319\end{array}$ & $\begin{array}{l}\mathrm{P}_{\mathrm{d}}=\underset{(0.1281)}{4,700.4}-\underset{(0.2112)}{0.000202 \mathrm{Q}_{\mathrm{d}}} \\
\mathrm{R}^{2}=0.8923\end{array}$ \\
\hline $\begin{array}{l}\text { Rest of the } \\
\text { World }\end{array}$ & $\begin{array}{l}\mathrm{P}_{0}=-\underset{(0.1820)}{-10980.4+0.003112 Q_{0}}(0.1528) \\
\mathrm{R}^{2}=0.9081\end{array}$ & $\begin{array}{l}\mathrm{P}_{\mathrm{d}}=\underset{(0.2015)}{3900.3-0.000245 \mathrm{Qd}_{\mathrm{d}}} \\
\mathrm{R}^{2}=0.7941\end{array}$ \\
\hline
\end{tabular}

The tariffs for the NAFTA and UEMFTA regions were obtained from Secretaria de Comercio y Fomento Industrial (SECOFI, 1994 and 2000), the tariffs among the rest of the world were obtained from the World Trade Organization (WTO, 2009).

Since simulation of the cucumber world market is a speculative task due to the assumptions implied, the difficulty of finding disaggregated data to feed the model, and the difficultly of modeling the fact that some countries import this commodity not only for domestic consumption, but also for trade to third parties, some appealing scenarios could not be constructed.

Several scenarios were developed in this study; however, only four were selected to be presented in this study. In addition, for the description and analysis of the results, only some relevant aspects are mentioned. 
The first scenario modeled the situation of the international market with tariffs and transport costs of the year 2000 (scenario base). The results from their solution are presented in Tables 3 and 4 . This scenario main objective was to validate and calibrate the model. To that, the results of the model were compared with the cucumber commercial flows, data published by FAOSTAT (production, consumption, importation and exportation, as well as, pricing for the year 2000). The model results are consistent with FAOSTAT published data (in general, the results from the model underestimate or overestimate published data in about $4 \%$ ).

Table 3. Solution Matrix of Commercial trade from Scenario 1 (quantities in thousand of Mt)

\begin{tabular}{|c|r|r|r|r|r|r|r|}
\hline & Mexico & US & Canada & EU & China & $\begin{array}{c}\text { Rest of } \\
\text { the } \\
\text { World }\end{array}$ & $\begin{array}{c}\text { Total } \\
\text { Supply }\end{array}$ \\
\hline Mexico & 119.6 & 338.3 & & & & & 457.9 \\
\hline US & & $1,051.3$ & 27.7 & & & & $1,079.0$ \\
\hline Canada & & & 170.6 & & & & 170.6 \\
\hline EU & & & & $1,539.3$ & & 56.1 & $1,595.4$ \\
\hline China & & & & & $19,899.1$ & & $19,899.1$ \\
\hline $\begin{array}{c}\text { Rest of } \\
\text { the } \\
\text { World }\end{array}$ & & & & & & 10.100 .5 & 10.100 .5 \\
\hline $\begin{array}{c}\text { Total } \\
\text { Demand }\end{array}$ & 119.6 & $1,389.6$ & 198.3 & $1,539.3$ & $19,899.1$ & 10156.6 & $33,302.6$ \\
\hline
\end{tabular}

Table 4. Demand and Supply Prices from Scenario 1 (US dollars/Mt)

\begin{tabular}{|l|c|c|}
\hline & Supply Price & Demand Price \\
\hline Mexico & 526.68 & 611.68 \\
\hline USA & 581.68 & 675.68 \\
\hline Canada & 665.68 & 690.68 \\
\hline EU & 629.75 & 667.75 \\
\hline China & 630.76 & 680.76 \\
\hline Rest of the World & 640.23 & 719.20 \\
\hline
\end{tabular}

The second scenario models the trade conditions that existed before the implementation of NAFTA in 1994. At that time, EUMFTA did not exist, just as China was not a member of the WTO, which is also included in the 
model. The results of this scenario are shown in Tables 5 and 6 . Under this scenario Mexico, export only to the USA.

Table 5. Commercial Trade from Scenario 2 (thousands of Mt).

\begin{tabular}{|c|c|c|c|c|c|r|r|}
\hline & Mexico & US & Canada & EU & China & $\begin{array}{c}\text { Rest of } \\
\text { the } \\
\text { World }\end{array}$ & $\begin{array}{c}\text { Total } \\
\text { Supply }\end{array}$ \\
\hline Mexico & 132.9 & 257.5 & & & & 52.0 & 442.4 \\
\hline US & & $1,117.8$ & & & & & $1,117.8$ \\
\hline Canada & & & 184.4 & & & & 184.4 \\
\hline EU & & & & $1,553.1$ & & 33.2 & $1,586.3$ \\
\hline China & & & & & $19,899.1$ & & $19,899.1$ \\
\hline $\begin{array}{c}\text { Rest of } \\
\text { the World }\end{array}$ & & & & & & $10,096.8$ & $10,096.8$ \\
\hline $\begin{array}{c}\text { Total } \\
\text { Demand }\end{array}$ & 132.9 & $1,375.3$ & 184.4 & $1,553.1$ & $19,899.1$ & $10,131.0$ & $33,326.8$ \\
\hline
\end{tabular}

Table 6. Demand and Supply Prices from Scenario 2 (US dollars/Mt)

\begin{tabular}{|l|c|c|}
\hline & Supply Price & Demand Price \\
\hline Mexico & 512.85 & 597.85 \\
\hline USA & 621.85 & 715.85 \\
\hline Canada & 675.80 & 700.80 \\
\hline EU & 623.85 & 661.85 \\
\hline China & 630.76 & 680.76 \\
\hline Rest of the World & 638.27 & 717.27 \\
\hline
\end{tabular}

The third scenario models a full operation of both NAFTA and EUMFTA implying zero tariffs among members of each treaty. This scenario models China as a no member of the WTO. The results of this scenario are presented in Tables 7 and 8.

Table 7. Commercial trade from Scenario 3 (thousands of Mt)

\begin{tabular}{|c|r|r|r|r|r|r|r|}
\hline & Mexico & US & Canada & EU & China & $\begin{array}{c}\text { Rest of } \\
\text { the } \\
\text { World }\end{array}$ & $\begin{array}{c}\text { Total } \\
\text { Supply }\end{array}$ \\
\hline Mexico & 104.1 & 305.2 & 22.1 & 44.3 & & & 475.7 \\
\hline US & & $1,082.9$ & & & & & $1,082.9$ \\
\hline Canada & & & 173.4 & & & & 173.4 \\
\hline EU & & & & $1,506.8$ & & 80.1 & $1,586.9$ \\
\hline China & & & & & $19,899.1$ & & $19,899.1$ \\
\hline $\begin{array}{c}\text { Rest of } \\
\text { the World }\end{array}$ & & & & & & $10,097.4$ & $10,097.4$ \\
\hline $\begin{array}{c}\text { Total } \\
\text { Demand }\end{array}$ & 104.1 & $1,388.2$ & 195.5 & $1,551.0$ & $19,899.1$ & 10177.5 & $33,315.4$ \\
\hline
\end{tabular}


Table 8. Demand and Supply Prices from Scenario 3 (US dollars/Mt)

\begin{tabular}{|l|c|c|}
\hline & Supply Price & Demand Price \\
\hline Mexico & 542.74 & 627.74 \\
\hline US & 585.74 & 679.74 \\
\hline Canada & 667.74 & 692.74 \\
\hline EU & 624.74 & 662.74 \\
\hline China & 630.76 & 680.76 \\
\hline Rest of the World & 638.56 & 717.56 \\
\hline
\end{tabular}

In order to gain a better perspective of the economic impact from the implementation of NAFTA and EUMFTA, Scenario 3 is compared to Scenario 2. With NAFTA and EUMFTA, the commercial flows of the cucumber market have undergone some changes due to the integration of these commercial blocks. For instance, Mexico increased production, reduced consumption, increased cucumber exports, as well as, showed a greater variety in their export destinations. Mexico increases its exports to US, and now exports to Canada and the EU, however reducing exports to the Rest of the World. Other significant facts are that Mexico has a $20 \%$ increment in its exports, a $5.8 \%$ increment in supply prices, and a $5 \%$ increment in demand prices, which represents additional income for Mexican cucumber producers.

The complete operation of NAFTA and EUMFTA generated changes in the cucumber commercial flow mainly between the countries that signed these treaties. Mexico benefited from the implementation of NAFTA and EUMFTA because it expanded its exports to Canada and the EU, although slightly reducing its exports to the US. In addition, Mexican producers benefited selling their products at 16 dollars/Mt over the price in the first scenario. Nevertheless, Mexican consumers face higher prices. Mexico has the lowest supply and demand prices suggesting that Mexico is highly competitive in terms of this commodity.

The fourth scenario models a complete execution of both NAFTA and EUMFTA implying zero tariffs among members of each treaty; also, this scenario considers the incorporation of China in the WTO, with China having the same trade conditions as existing WTO members. The results of this scenario are shown in Tables 9 and 10.

When comparing Scenario 4 with Scenario 3, the results show that the countries that signed NAFTA and EUMFTA have had no impact on the amount of trade or prices. Therefore, the results of this scenario suggest that 
the incorporation of China into the WTO has had no effect in the cucumber market among NAFTA and EUMFTA countries, because of the commercial protection granted by these treaties to its members. Small changes in trade and prices occurred between China and the Rest of the World.

Table 9. Commercial Trade from Scenario 4 (thousands of Mt).

\begin{tabular}{|c|c|c|c|c|c|c|c|}
\hline & Mexico & US & Canada & EU & China & $\begin{array}{l}\text { Rest of the } \\
\text { World }\end{array}$ & $\begin{array}{l}\text { Total } \\
\text { Supply }\end{array}$ \\
\hline Mexico & 104.1 & 305.2 & 22.1 & 44.3 & & & 475.7 \\
\hline US & & $1,082.9$ & & & & & $1,082.9$ \\
\hline Canada & & & 173.4 & & & & 173.4 \\
\hline EU & & & & $1,506.8$ & & 80.9 & $1,587.6$ \\
\hline China & & & & & $19,855.8$ & & $20,052.5$ \\
\hline $\begin{array}{c}\text { Rest of the } \\
\text { World }\end{array}$ & & & & & & $10,077.8$ & $10,077.8$ \\
\hline $\begin{array}{c}\text { Total } \\
\text { Demand }\end{array}$ & 104.1 & $1,388.2$ & 195.5 & $1,551.0$ & $19,855.8$ & $10,158.7$ & $33,449.9$ \\
\hline
\end{tabular}

Table 10. Demand and Supply Prices from Scenario 4 (US dollars/Mt)

\begin{tabular}{|l|c|c|}
\hline & Supply Price & Demand Price \\
\hline Mexico & 542.74 & 627.74 \\
\hline US & 585.74 & 679.74 \\
\hline Canada & 667.74 & 692.74 \\
\hline EU & 624.74 & 662.74 \\
\hline China & 639.50 & 689.50 \\
\hline Rest of the World & 635.08 & 714.08 \\
\hline
\end{tabular}

The fifth scenario modeled free trade and zero tariffs for the entire World. The results are shown in Tables 11 and 12.

Table 11. Commercial Trade from Scenario 5 (thousands of Mt).

\begin{tabular}{|c|r|r|r|r|r|r|r|}
\hline & Mexico & US & Canada & EU & China & $\begin{array}{c}\text { Rest of the } \\
\text { World }\end{array}$ & $\begin{array}{c}\text { Total } \\
\text { Supply }\end{array}$ \\
\hline Mexico & 91.4 & 287.7 & & 111.3 & & & 490.4 \\
\hline US & & $1,095.7$ & & & & & $1,095.7$ \\
\hline Canada & & & 184.4 & & & & 184.4 \\
\hline EU & & & & $1,408.7$ & & 299.2 & $1,608.1$ \\
\hline China & & & & & $19,833.2$ & & $20,132.4$ \\
\hline $\begin{array}{c}\text { Rest of the } \\
\text { World }\end{array}$ & & & & & & 10103.5 & 10103.5 \\
\hline $\begin{array}{c}\text { Total } \\
\text { Demand }\end{array}$ & 91.4 & $1,383.4$ & 184.4 & $1,520.0$ & $19,833.2$ & $10,402.7$ & $33,614.7$ \\
\hline
\end{tabular}


Table 12. Demand and Supply Prices from Scenario 5 (Dollars/Mt).

\begin{tabular}{|l|c|c|}
\hline & Supply Price & Demand Price \\
\hline Mexico & 555.99 & 640.99 \\
\hline US & 598.99 & 692.99 \\
\hline Canada & 675.80 & 700.80 \\
\hline EU & 637.99 & 675.99 \\
\hline China & 644.06 & 694.06 \\
\hline Rest of the World & 647.49 & 697.82 \\
\hline
\end{tabular}

This scenario, when compared to the third and fourth scenarios, shows that the Mexican cucumber is still competitive under a zero tariffs worldwide situation, since it has a lower supply price that allow for its incremented exports. However, with the fifth scenario, there are significant changes in the commercial flows among the studied regions.

\section{Concluding Remarks}

The focus of this study has been the potential effects of NAFTA, EUMFTA and the integration of China to the WTO under several commercial policies, in the cucumber world market. A spatial equilibrium model with endogenous prices was used for this purpose. Since, simulation of any commodity in a world market perspective is a speculative task some appealing scenarios were not constructed. This is due to the assumptions implied, the difficulty of finding disaggregated data to feed the model, and the difficultly of modeling the fact that some countries import commodities not only for domestic consumption, but also for trade to third parties. Several key remarks emerge from this study.

1. The complete implementation of NAFTA and EUMFTA generated changes in the cucumber commercial flow among the countries that signed these treaties, benefiting Mexican producers.

2. The incorporation of China as a member of the WTO did not affect significantly the cucumber commercial flows and prices in a world market perspective.

3. Mexican cucumber production is highly competitive, in the world market, because it has the lowest supply prices.

4. Finally, further research could be oriented on the estimation of the benefit shares from NAFTA, EUMFTA and the incorporation of CHINA to the WTO. 


\section{References}

Enke, S. 1951. Equilibrium Among Spatially Separated Markets: Solution by Electric Analogue. Econometrica, Vol. 57: 591-600.

ERS/USDA http://wwwers.usda.gov/ Briefing/NAFTA/MexicoTrade.htm

ERS/USDA http://wwwers.usda.gov/Briefing/China/trade.htm

FAOSTAT/FAO Statistical Databases http://faostat.fao.org/

Guajardo, R. \& H. Elizondo. 2003. North American Tomato Market: A Spatial Perspective. Applied Economics. Vol. 53: 315-322.

Guajardo R. \& P. Villezca. 2004. Impacto de la Apertura Comercial de México y de su integración en Bloques Comerciales en el Mercado Mundial del Limón. Estudios Económicos, Vol.19: 61-92.

Kawaguchi, T., N. Suzuki \& H. Kaiser. 1998. A Spatial Equilibrium Model for Imperfectly Competitive Milk Markets. American Journal of Agricultural Economics. Vol. 79: 851-9.

Kennedy L. \& C. Atici. 1998. A Sectoral Analysis of Agricultural Trade Liberalization. Journal of Agricultural and Applied Economics. Vol. 30: 277-284.

Kennedy, P. L. \& K. Hughes. 1998. Welfare Effects of Agricultural Trading Blocks: The Simulation of a North American Customs Union. Journal of Agricultural and Resource Economics. Vol.23: 99-110.

Nelson, C. H. \& B. A. Mc Carl. 1984. Including Imperfect Competition in Spatial Equilibrium Models. Canadian Journal of Agricultural Economics. Vol. 32: 55-70.

Samuelson, P. 1952. Spatial Price Equilibrium and Lineal Programming. American Economic Review. Vol. 52: 283-303.

SECOFI. 1994. Fracciones Arancelarias y Plazos de Desgravación, Tratado de Libre Comercio de América del Norte, México.

SECOFI. 2000. Fracciones Arancelarias y Plazos de Desgravación, Tratado de Libre Comercio México- Unión Europea, México.

Takayama Y. \& G. Judge. 1971. Spatial and Temporal Price and Allocation Models. Amsterdam: North Holland Publishing Co.

WTO. 2009. Tariffs on Imports. Geneva, Switzerland. 